\title{
PENGARUH DUE PROFESSIONAL CARE TERHADAP KUALITAS AUDIT PADA KANTOR AKUNTAN PUBLIK DI KOTA BANDUNG
}

\author{
Tb. Aman Faturachman \\ Angga Nugraha \\ (Universitas Pendidikan Indonesia)
}

\begin{abstract}
ABSTRAK
Tujuan penelitian ini adalah untuk mengetahui bagaimana pengaruh due professional care terhadap kualitas audit. Studi kasus pada Kantor Akuntan Publik di Kota Bandung. Hipotesis dalam penelitian ini adalah due professional care berpengaruh positif terhadap kualitas audit. Metode penelitian yang digunakan dalam penelitian ini adalah metode asosiatif. Populasi pada penelitian ini adalah auditor junior dan auditor senior yang bekerja pada Kantor Akuntan Publik di Kota Bandung. Pengambilan sampel menggunakan convenience sampling. Data yang digunakan data primer yang dikumpulkan dari hasil kuesioner. Dalam menganalisis data, penelitian ini menggunakan analisis statistik yang bernama korelasi product moment. Dari hasil pengujian didapatkan pengaruh yang positif sebesar 0,569 serta koefisien determinasi sebesar 32,37\%. Hasil ini menunjukkan bahwa due professional care berpengaruh terhadap kualitas audit sebesar $32,37 \%$.
\end{abstract}

\section{Kata kunci: Due Professional Care, Kualitas Audit}

\section{PENDAHULUAN}

Dalam dunia bisnis, perusahaan pada umumnya menginginkan kualitas terbaik bagi pelanggannya baik bisnis, manufaktur maupun jasa. Ketika keinginan tersebut telah tercapai, perusahaan harus mempertahankan eksistensi dan perkembangannya. Untuk mempertahankan eksistensi dan perkembangannya, setiap perusahaan harus selalu memperbaiki kegiatan operasi perusahaannya. Hasil dari operasi suatu perusahaan selama satu periode tertentu dapat terlihat pada laporan keuangan suatu perusahaan. Laporan keuangan yang disajikan selama periode tersebut akan dilakukan pemeriksaan (audit) yang bertujuan untuk mengetahui apakah laporan keuangan tersebut telah disajikan secara benar dan wajar. Audit atas laporan keuangan memegang peran yang sangat penting dalam perekonomian dan dunia bisnis. Informasi yang andal sangat dibutuhkan masyarakat sebagai pengambilan keputusan ekonomi kedepan. Informasi akan lebih dipercaya dan akuntabel apabila informasi tersebut telah dilakukan audit oleh pihak independen yaitu auditor pada suatu kantor akuntan publik (KAP) dalam bentuk opini atas laporan keuangan. 
Audit adalah pengumpulan dan evaluasi bukti tentang informasi untuk menentukan dan melaporkan derajat kesesuaian antara informasi itu dan kriteria yang telah ditetapkan. Audit harus dilakukan oleh orang yang kompeten dan independen. Hal ini bertujuan agar hasil audit dapat berguna bagi pihak-pihak yang membutuhkannya. (Arens :2012).

De Angelo dalam Kusharyanti (2003) mendefinisikan kualitas audit sebagai kemungkinan (joint probability) dimana seorang auditor akan menemukan dan melaporkan pelanggaran yang ada dalam sistem akuntansi kliennya. Kemungkinan dimana auditor akan menemukan salah saji tergantung pada kualitas pemahaman auditor (kompetensi) sementara tindakan melaporkan salah saji tergantung pada independensi auditor.

Ikatan Akuntansi Indonesia (IAI), dalam Standar Profesional Akuntan Publik (2001) menyebutkan kualitas pelaksanaan audit selalu mengacu pada standar-standar yang ditetapkan, meliputi standar umum, standar pekerjaan dan standar pelaporan. Standar umum merupakan cerminan kualitas pribadi yang harus dimiliki oleh seorang auditor yang mengharuskan auditor untuk memiliki keahlian dan pelatihan teknis yang cukup dalam melaksanakan prosedur audit. Sedangkan standar pekerjaan lapangan dan standar pelaporan mengatur auditor dalam hal pengumpulan data dan kegiatan lainnya yang dilaksanakan selama melakukan audit serta mewajibkan auditor untuk menyusun suatu laporan atas laporan keuangan yang diauditnya secara keseluruhan.

Namun dalam pelaksanaannya banyak yang menyalahi peraturan maupun prosedur audit. Sehingga menimbulkan citra yang buruk bagi auditor di masyarakat. Terdapat beberapa kasus auditor yang terjadi di Indonesia sehingga pada tahun 2008 dan 2009 Menteri Keuangan memberikan sanksi terhadap beberapa kantor akuntan public yang dinyatakan bersalah melakukan pelanggaran yang berujung pada pembekuan izin kerja kantor akuntan publik.

Kualitas audit erat kaitannya dengan due professional care. karena ketika auditor ingin menghasilkan laporan audit yang berkualitas, auditor harus menerapkan due professional care dalam setiap penugasan auditnya. Penggunaan kemahiran profesional dengan cermat dan seksama memungkinkan auditor untuk memperoleh keyakinan memadai bahwa laporan keuangan bebas dari salah saji material, baik yang disebabkan oleh kekeliruan maupun kecurangan.

Penelitian sebelumnya yang dilakukan oleh (Pancawati Hardiningsih \& Rachmawati Meita Oktaviani : 2012) membuktikan bahwa Due Professional Care mempunyai pengaruh positif terhadap kualitas audit. Hasil ini menunjukkan bahwa auditor selalu melakukan review secara kritis pada setiap tingkat supervise terhadap pelaksanaan audit dan terhadap setiap pertimbangan audit maka auditor akan selalu menjaga kualitas hasil auditnya.

Berbeda dengan hasil penelitian dari (Saripudin, Netty Herawaty, Rahayu : 2012) yang menyebutkan bahwa Secara parsial variabel due professional care tidak berpengaruh signifikan terhadap kualitas auditor. Sehingga due professional 
care yang dimiliki auditor belum tentu meningkatkan kualitas audit yang dihasilkan.

Due professional care memiliki arti kemahiran professional yang cermat dan seksama (PSA No.4 SPAP 2011). Singgih dan Bawono (2010) menyebutkan bahwa kecermatan dan keseksamaan dalam penggunaan kemahiran profesional menuntut auditor untuk melaksanakan skeptisme profesional. Sikap auditor yang berpikir kritis terhadap bukti audit dengan selalu mempertanyakan dan melakukan evaluasi terhadap bukti audit.

Penggunaan kemahiran profesional dengan cermat dan seksama memungkinkan auditor untuk memperoleh keyakinan memadai bahwa laporan keuangan bebas dari salah saji material, baik yang disebabkan oleh kekeliruan maupun kecurangan. Auditor harus menggunakan keahlian profesionalnya dengan cermat dan seksama (due professional care) dan secara hati-hati (prudent) dalam setiap penugasan. Due professional care dapat diterapkan dalam pertimbangan professional (professional judgment), meskipun dapat saja terjadi penarikan kesimpulan yang tidak tepat ketika audit sudah dilakukan dengan seksama Penerapan kecermatan dan keseksamaan diwujudkan dengan dilakukannya review secara kritis pada setiap tingkat supervise terhadap pelaksanaan audit. Kecermatan dan keseksamaan menyangkut apa yang dikerjakan auditor dan bagaimana kesempurnaan pekerjaan yang telah dihasilkan.

Penelitian terkait hubungan due professional care terhadap kualitas audit ini mengacu pada penelitian yang dilakukan oleh pancawati 2012 yang berjudul pengaruh due professional care, etika, dan tenur terhadap kualitas audit. Perbedaan penelitian ini dengan penelitian sebelumnya adalah terletak pada pembahasan variabelnya dimana peneliti sebelumnya meneliti tentang due professional care, etika dan tenur. Sedangkan peneliti hanya meneliti variabel due professional care. Selain itu, peneliti sebelumnya yang memilih studi kasus di daerah Jawa Tengah dan Jawa Timur, peneliti lebih tertarik melakukan penelitian di Kota Bandung. Hal ini dikarenakan KAP yang ada di Kota Bandung lebih banyak dan memiliki karakteristik yang berbeda antara auditor di Jawa Tengah dan Jawa Timur dengan yang ada di Kota Bandung.

Berdasarkan uaraian di atas maka peneliti ingin meneliti kembali dengan judul "Pengaruh Due Professional Care terhadap Kualitas Audit pada KAP di Kota Bandung".

\section{Rumusan Masalah}

Berdasarkan uraian latar belakang masalah yang telah dipaparkan sebelumnya, maka rumusan masalah yang akan dijadikan pokok bahasan dalam penelitian ini, yaitu: (1) Bagaimana gambaran umum tentang due professional care pada auditor pada KAP di Bandung; (2) Bagaimana gambaran umum tentang kualitas audit pada auditor pada KAP di Bandung; (3) Bagaimana pengaruh due professional care terhadap kualitas audit pada auditor pada KAP di Bandung. 


\section{KAJIAN PUSTAKA}

Suatu perusahaan dalam menyajikan suatu laporan keuangan memungkinkan adanya salah saji atau kecurangan dalam laporan keuangan tersebut. oleh karena itu perlu di evaluasi dengan cara dilakukannya pemeriksaan (audit) terhadap laporan keuangan suatu perusahaan, yang bertujuan untuk mengetahui apakah laporan keuangan telah disajikan secara benar dan wajar. Dalam hal ini peran auditor dibutuhkan dalam melakukan audit. Auditor diperlukan oleh suatu perusahaan untuk mengurangi adanya resiko informasi yang disajikan dalam suatu laporan keuangan.

Audit adalah proses untuk memverifikasi informasi dengan kriteria yang sudah ditetapkan oleh standar yang berlaku umum. Audit dilakukan oleh seorang yang profesional dan independen hal ini bertujuan agar hasil audit dapat berguna bagi pihak-pihak yang membutuhkannya. Timbulnya konflik kepentingan antara agent dengan principal disebabkan karena adanya konflik kepentingan antara keduanya. Hal tersebut menyebabkan auditor dituntut untuk melakukan kecermatan dan ketelitian secara seksama yang dikenal dengan Due Professional Care sehingga mampu mendeteksi kecurangan ataupun kesalahan dalam auditnya.

Due professional care memiliki arti kemahiran professional yang cermat dan seksama (PSA No.4 SPAP 2011). Kecermatan dan keseksamaan dalam penggunaan kemahiran profesional menuntut auditor untuk melaksanakan skeptisme profesional. Sikap auditor yang berpikir kritis terhadap bukti audit adalah dengan selalu mempertanyakan dan melakukan evaluasi terhadap bukti audit. Penggunaan kemahiran profesional dengan cermat dan seksama memungkinkan auditor untuk memperoleh keyakinan memadai bahwa laporan keuangan bebas dari salah saji material, baik yang disebabkan oleh kekeliruan maupun kecurangan. Auditor harus menggunakan keahlian profesionalnya dengan cermat dan seksama (dueprofessional care) dan secara hati-hati (prudent) dalam setiap penugasan. Due professional care dapat diterapkan dalam pertimbangan profesional (professional judgment), meskipun dapat saja terjadi penarikan kesimpulan yang tidak tepat ketika audit sudah dilakukan dengan seksama Penerapan kecermatan dan keseksamaan diwujudkan dengan dilakukannya review secara kritis pada setiap tingkat supervise terhadap pelaksanaan audit. Kecermatan dan keseksamaan menyangkut apa yang dikerjakan auditor dan bagaimana kesempurnaan pekerjaan yang telah dihasilkan.

Due professional care merupakan hal yang penting yang harus diterapkan bagi setiap akuntan publik dalam melaksanakan tugas profesionalnya agar dicapai kualitas audit yang memadai. Due professional care menyangkut dua aspek, yaitu skeptisme professional dan keyakinan yang memadai. Hasil penelitian kopp, Morley, dan Rennie dalam Mansur (2007:38) membuktikan bahwa masyarakat mempercayai laporan keuangan jika auditor telah menggunakan sikap skeptis profesionalnya (professional skepticism) dalam proses melaksanakan audit. Auditor harus tetap menjaga sikap skeptis profesionalnya selama proses 
pemeriksaan, karena ketika auditor sudah tidak mampu lagi mempertahankan sikap skeptis profesionalnya, maka laporan keuangan yang telah diaudit tidak dapat dipercaya lagi, dan memumgkinkan adanya litigasi paska audit.

Menurut Government Accountability Office (GAO) (2007:116) dalam Mansur (2007:42), audit yang sesuai harus memberikan keyakinan yang memadai (reasonable assurance) bahwa bukti audit telah dicukupi dan sesuai untuk mendukung temuan dan kesimpulan auditor. Keyakinan yang memadai atas buktibukti yang ditemukan akan sangat membantu auditor dalam menentukan lingkup dan metodologi yang akan digunakan dalam melaksanakan pekerjaan audit agar tujuan dapat tercapai. Dengan demikian Due professional care berkaitan dengan kualitas audit.

Due professional care erat kaitannya dengan Kualitas audit. karena ketika auditor ingin menghasilkan laporan audit yang berkualitas, auditor harus menerapkan due professional care dalam setiap penugasan auditnya. Penggunaan kemahiran profesional dengan cermat dan seksama memungkinkan auditor untuk memperoleh keyakinan memadai bahwa laporan keuangan bebas dari salah saji material, baik yang disebabkan oleh kekeliruan maupun kecurangan.

Kualitas audit dianggap penting bagi pengguna laporan keuangan, karena dengan semakin tingginya kualitas audit maka akan dihasilkan laporan keuangan yang dapat dipercaya dan dapat dipergunakan oleh para pihak yang berkepentingan di dalam dan di luar perusahaan untuk mengambil keputusan. Selain itu semakin tingginya kualitas audit juga dapat memperkecil kekhawatiran akan adanya skandal keuangan yang dapat mengurangi rasa kepercayaan publik terhadap laporan keuangan yang telah diaudit akuntan publik.

Penelitian mengenai due professional care terhadap kualitas audit pernah diteliti oleh Rahman (2009) yang menguji due professional care terhadap kualitas audit, hasil penelitiannya menunjukkan bahwa due professional care berpengaruh signifikan terhadap kualitas audit. Kemudian, penelitian Hardiningsih, Pancawati dan Meita Oktaviani, Rachmawati (2012) dan Dwi Dayanti Oktavia (2013) mendapatkan hasil bahwa due professional care memiliki pengaruh yang signifikan dan positif terhadap kualitas audit. Penelitian Mansur (2007) dan Singgih Bawono (2010) membuktikan bahwa sikap skeptisme dan keyakinan yang memadai berpengaruh positif terhadap kualitas audit. Hasil ini menunjukkan bahwa auditor selalu melakukan review secara kritis pada setiap tingkat supervise terhadap pelaksanaan audit dan terhadap setiap pertimbangan audit maka auditor akan selalu menjaga kualitas hasil auditnya. Penelitian ini mendukung penelitian yang diteliti oleh Muliani dan Bawono (2010) yang menyebutkan bahwa due professional care secara simultan berpengaruh terhadap kualitas audit.

Ketika, auditor menggunakan due professional care dalam tugas auditnya memungkinkan auditor memperoleh keyakinan memadai bahwa laporan keuangan bebas dari salah saji material, baik yang disebabkan oleh kekeliruan atau 
kecurangan. Hal tersebut dilakukan tentunya agar menghasilkan laporan audit yang berkualitas sehingga berguna bagi para pengambil keputusan.

Hal tersebut bisa digambarkan dalam bagan di bawah ini:

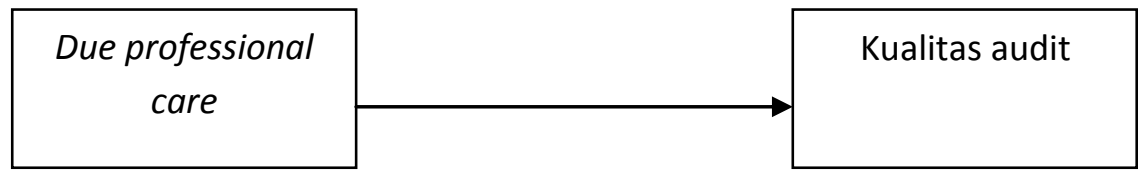

\section{Gambar Hubungan Variabel}

Berdasarkan penjelasan kerangka teoritis di atas maka penulis mengambil hipotesis yaitu Due professional care berpengaruh positif terhadap kualitas audit

\section{METODE PENELITIAN}

Objek dalam penelitian ini adalah due professional care dan kualitas audit pada Kantor Akuntan Publik di Kota Bandung. Metode ini menggunakan metode penelitian analisis deskriptif. Data penelitian yang dibutuhkan adalah data primer dalam bentuk persepsi responden (subjek) penelitian. Pengambilan data menggunakan observasi langsung dan instrument yang digunakan adalah kuisioner (angket). Teknik yang digunakan untuk menganalisis data dalam penelitian ini adalah dengan menggunakan metode kuantitatif.

\section{Populasi Dan Sampel Penelitian}

Populasi dalam penelitian ini adalah para auditor yang bekerja di 28 Kantor Akuntan Publik di Bandung dengan tingkatan auditor senior dan junior, yang berjumlah 346 orang. Adapun dalam penelitian ini, teknik sampling yang digunakan adalah Convenience Sampling. Responden dalam penelitian ini adalah auditor junior dan auditor senior yang bekerja pada Kantor Akuntan Publik di Kota Bandung. Teknik pengambilan sampel menggunakan rumus Slovin sehingga sampel yang diambil pada penilitian ini sebanyak 77 orang.

\section{Teknik Analisis Data}

\section{Uji Reliabilitas dan Validitas}

Untuk mengetahui bahwa pernyataan yang digunakan dalam instrument reliable, maka digunakan Cronbach Alpha. Instrument dikatakan valid jika memiliki nilai Cronbach Alpha lebih besar dari 0,60. Untuk melihat validitas masing-masing instrument yang digunakan, peneliti menggunakan koefisien Factor Analysis. Suatu instrument dikataan valid jika memiliki nilai koefisien validitasnya lebih besar dari 0,3 .

\section{HASIL DAN PEMBAHASAN}

\section{Pengaruh Due Profesional Care Terhadap Kualitas Audit}

Untuk mengetahui pengaruh masing-masing variabel bebas terhadap variabel terikat, maka dalam penelitian ini dilakukan uji parsial (uji t) yaitu dengan $\mathrm{t}_{\text {kitung }}$ dengan $\mathrm{t}_{\text {tabel }}$ dan dengan membandingkan nilai signifikansi sebesar 
0,05. Jika $\mathrm{t}_{\text {hitung }}>\mathrm{t}_{\text {tabel }}$ dan nilai signifikansi $<0,05$ maka Ho di tolak, dan jika $\mathrm{t}_{\text {kitung }}<\mathrm{t}_{\text {tabel }}$ dan nilai signifikansi $>0,05$ maka Ho di terima.

Tabel 4.39

Hasil Uji t

\begin{tabular}{|c|c|c|c|c|c|c|}
\hline \multirow{2}{*}{\multicolumn{2}{|c|}{ Model }} & \multicolumn{2}{|c|}{$\begin{array}{c}\text { Unstandardized } \\
\text { Coefficients }\end{array}$} & $\begin{array}{l}\text { Standardized } \\
\text { Coefficients }\end{array}$ & \multirow[t]{2}{*}{$\mathrm{T}$} & \multirow[t]{2}{*}{ Sig. } \\
\hline & & B & $\begin{array}{l}\text { Std. } \\
\text { Error }\end{array}$ & Beta & & \\
\hline \multirow[t]{2}{*}{1} & (Constant) & 59,770 & 15,824 & & 3,777 &, 000 \\
\hline & $\begin{array}{l}\text { Due Professional } \\
\text { Care }\end{array}$ & ,772 & , 168 & ,569 & 4,585 & ,000 \\
\hline
\end{tabular}

Berdasarkan tabel di atas diketahui bahwa nilai $\mathrm{t}_{\text {hitung }}$ sebesar 4,585 lebih besar dari $\mathrm{t}_{\text {tabel }}$ sebesar 1,680 $(4,585>1,680)$ dengan nilai signifikansi sebesar 0,000 lebih kecil dari tingkat signifikansi 0,05. Dengan demikian, Ho ditolak dan Ha di terima yang artinya Due Professional Care berpengaruh secara parsial terhadap Kualitas Audit.

Sedangkan untuk mengetahui berapa besar persentase pengaruh Variabel due professional care terhadap kualitas audit dapat dilihat dari koefisien determinasi. Berikut ini adalah perhitungannya:

$$
\begin{aligned}
\mathrm{KD} & =\mathrm{r}^{2} \times 100 \\
& =0,569^{2} \times 100 \\
& =0,3237 \text { atau } 32,37 \%
\end{aligned}
$$

Berdasarkan perhitungan di atas, diketahui nilai koefisien determinasi, sebesar 0,3237 atau 32,37\%. Sehingga dapat disimpulkan bahwa Due Professional Care berpengaruh positif terhadap kualitas audit sebesar 32,37\%. Sedangkan sisanya, yaitu 67,63\% dipengaruhi oleh faktor lain yang tidak dibahas dalam penelitian ini. 


\section{SIMPULAN}

\section{Simpulan}

Berdasarkan hasil penelitian dan pembahasan mengenai "pengaruh due professional care terhadap kualitas audit", maka dapat ditarik simpulan sebagai berikut:

1. Due professional care yang dimiliki oleh auditor di Kota Bandung ketika melaksanakan tugas audit sudah baik. Hal ini tercermin pada hasil penelitian yang dapat ditunjukan pada seluruh jawaban responden dengan hasil akhir berupa kategori "tinggi".

2. Kualitas audit pada auditor Kantor Akuntan Publik di Kota Bandung sangat baik. Hal ini terlihat pada hasil penelitian yang dapat ditunjukan pada seluruh jawaban responden dengan hasil akhir berupa kategori "sangat tinggi".

3. Terdapat pengaruh yang kuat antara due professional care terhadap kualitas audit. Hal ini disebabkan oleh sikap due professional care yang dimiliki oleh auditor senior dan junior itu sendiri yang mampu mempengaruhi atas kualitas audit dalam penugasan audit atas laporan keuangan. Hal ini didukung oleh teori dari Mautz dan Sharaf yang menyatakan bahwa kesalahan dapat dideteksi jika auditor memiliki keahlian dan kecermatan. Temuan kesalahan pada laporan keuangan klien merupakan salah satu hal yang menunjukkan kualitas audit dan menunjukkan keahlian yang dimiliki oleh tim audit.

\section{Saran}

Berdasarkan hasil penelitian yang telah dilakukan, maka peneliti mengajukan beberapa saran sebagai berikut:

1. Untuk meningkatkan due professional care serta kualitas audit sebaiknya Kantor Akuntan Publik memberikan peningkatan pemahaman interpersonal dengan cara memahami dan mempelajari individu lain yang memiliki pandangan dan persepsi yang berbeda mengenai satu hal. agar auditor dapat memahami bagaimana sebab klien berperilaku ataupun klien bersikap sesuatu. Hal ini dapat membantu auditor ketika menggunakan sikap due professional care dalam setiap penugasan audit atas laporan keuangan.

2. Setiap supervisi KAP hendaknya memberikan pengawasan, penilaian, serta evaluasi kinerja terhadap setiap auditor. Hal ini dilakukan agar setiap kinerja para auditor dapat selalu terpantau oleh supervisi dan juga auditor bisa menghasilkan audit yang berkualitas.

3. Bagi peneliti selanjutnya yang akan melakukan penelitian sejenis sebaiknya menggunakan standar audit yang baru dikarenakan dalam penelitian ini masih menggunakan standar audit yang lama. Selain itu diharapkan mengganti variabel due professional care menjadi yang lain, seperti independensi, kompetensi, etika dll agar bisa menggali lebih dalam tentang apa saja yang bisa mempengaruhi kualitas audit 


\section{DAFTAR PUSTAKA}

Agus, Soekrisno. (2012) “Auditing” : Salemba Empat. Jakarta.

Alvin A.Arens, Randal J.Elder \& Mark S. Beasley. (2012) "Auditing and Assurance Services an Integrated Approach” International Edition

Anisma, Yuneita, Abidin, zainal dan Christina. 2011. Jurnal. Faktor-Faktor Yang Mempengaruhi Sikap Skeptisme Profesional Seorang Auditor Pada Kantor Akuntan Publik di Sumatera. Pekbis Jurnal. Vol. 3 (2): 490-497

American Institute of Certified Public Accountants (AICPA). (1978). "The

Commissionon Auditors Responsibilities: Report, Conclusions, and Recommendations." New York: AICPA.

Arens, Alvin A., et.al.(2008). Auditing dan Jasa Assurance (Pendekatan Terintegrasi) Jilid I. Erlangga: Jakarta.

Arikunto, Suharsimi. (2009). "Metode Penelitian":Rineke Cipta.

De Angelo, L.E. 1981. Auditor Size and Auditor quality. Journal of Accounting and economics 3.

Duff,A.2009."Measuring Audit Quality in Era of Change (An Empirical Investigation of UK Audit Market Stakeholders in 2002 and 2005)."Managerial Auditing Journal, Vol.24, No.5, pp.400-422.

Duwi Priyatno. 2010. Teknik Mudah dan Cepat Melakukan Analisis Data Penelitian denagn SPSS. Yogyakarta : Gava Media.

Financial Reporting Council (FRC). (2006). Discussion Paper Promoting Audit Quality

Ely Suhayati., \& Siti Kurnia Rahayu. (2010). AUDITING: Konsep Dasar dan Pedoman Pemriksaan Akuntan Publik. Yogyakarta : Graha Ilmu.

Ghozali, Imam. 2011. Aplikasi Analisis Multivariate dengan Program IBM SPSS19. Semarang: Badan Penerbit Universitas Diponegoro.

Henry Simamora. (2002). Auditing. Unit Penerbit dan Percetakan (UPP) AMP YKPN: Yogya.

Hurtt, R. K. 2007. "Professional Skepticism: An audit specific model an measurement scale." Working paper, Babylor University.

Hurtt K, Eining M, dan Plumplee. (2008). An Experimental Examination of Professional Skepticism. Journal. University of Winconsin, Madison.

Ikatan Akuntan Indonesia-Kompartemen Akuntan Publik (IAI-KAP).(2001). Standar Profesional Akuntan Publik. Salemba Empat: Jakarta

Ikatan Akuntan Indonesia. (2011). "Standar Profesional Akuntan Publik”. Jakarta : Salemba Empat.

International Federation of Accountants (IFAC). (2006). Handbook of International Auditing, "Assurance and Ethics Pronouncement." New York, NY: International Federation of Accountans

Jusup, Al. Haryono. (2001). Auditing : Pengauditan. Yogyakarta : STIE YKPN.

Halim, A. (2004). Auditing (Dasar-dasar Audit Laporan Keuangan) Jilid 1 Edisi Ketiga. Yogyakarta: UPP akademi Manajemen Perusahaan YKPN. 
Kusharyati. (2003). "Temuan penelitian mengenai kualitas audit dan kemungkinan topik penelitian di masa datang". Jurnal Akuntansi dan Manajemen (Desember). Hal. 25-60

Mardalis. (2009). “Metode Penelitian Suatu Pendekatan Proposal." Jakarta: Bumi Aksara.

Mautz, R.K. dan H.A. Sharaf. (1961). The Philosophy of Auditing. Sarasota, FL: American Accounting Association.

Mulyadi. (2009). Auditing. Cetakan ke-6. Jakarta: Salemba Empat

Noor, Juliansyah. (2013). "Metodologi Penelitian Skripsi, Tesis, Disertasi, \& Karya Ilmiah". Jakarta : Kencana Prenada Media Group.

Noviyanti, Suzy. (2008). Skeptisme Profesional Auditor dalam Mendeteksi Kecurangan. Jurnal Akuntansi dan Keuangan Indonesia. Vol. 5 (1): 102125

Pancawati, H., \& Rachmawati, M, O,. (2012). Pengaruh Due Professional Care, Etika, dan Tenur Terhadap Kualitas Audit. Fakultas Ekonomi Unisbank Semarang.

Riduwan. (2010). "Pengantar Statistika". Bandung: Alfabeta

Singgih, E., \& Bawono, I. (2010). Faktor-faktor Dalam Diri Auditor dan Kualitas Audit. Universitas Jendral Sudirman Purwokerto.

Standar Profesional Akuntan Publik. 31 Maret 2011. Jakarta : Penerbit Salemba Empat

Somantri, Ating. (2006).“Aplikasi Statistika dalam Penelitian”. Bandung : CV Pustaka Setia.

Sudjana. (2005). Metode Statistika. Bandung: Tarsito

Sugiyono (2010). "Metode Penelitian Bisnis". Bandung : Alfabeta

Tuanakotta, T. M. (2011). "Berpikir Kritis dalam Auditing”. Jakarta: Salemba Empat

Tuanakotta, T. M. (2013). “Audit Berbasis ISA.” Jakarta: Salemba Empat http://www.scribd.com 